\title{
"The Horrible Lady" in Istanbul: is a public non-Imperial female Portrait possible in the sixth Century AD?
}

\begin{abstract}
In 1963 the Archaeological Museum of Istanbul purchased a female portrait of unknown provenance. It is clearly recut from an older head. In its final version the head is late antique, but the recutting and the scarcity of comparable non-Imperial female portraits from this period have made a more secure dating difficult. Here the first half of the sixth century $\mathrm{AD}$ is proposed. This article poses two main questions: 1) Is a non-Imperial female portrait in the round possible as late as the sixth century? 2) Could a woman in a period when covered heads were the norm, have herself portrayed with uncovered hair?
\end{abstract}

Among the portraits in the Archaeological Museum in Istanbul a female head called "the Horrible Lady" stands out as a hapax (FIGS. 1-3). The head, which is made from Proconnesian marble, was purchased in Istanbul in 1963. ${ }^{1}$ Its provenance is unknown. The height of the head is $27,9 \mathrm{~cm}$, height from chin to crown $22,2 \mathrm{~cm}$, breadth $22,9 \mathrm{~cm}$. This is roughly life size, if perhaps a bit on the small side.

The head is well preserved, partly thanks to the fact that it has few protruding elements. Since the nose is almost flat, the head (minus the neck) forms a sphere, height and breadth being almost equal.

As it is sculpted in the round and has life-size measurements, the head has been published as a portrait. This seems indeed the most likely function for it, and it gives every appearance of having been recut from an older head. The scarcely protruding facial features are characteristic of Marina Prusac's "Bandit Group". ${ }^{2}$ As parallels to the extreme flatness of the face, one may mention a sixth century recut male portrait from Ephesos ${ }^{3}$ (FIG. 4), and a porphyry

\footnotetext{
${ }^{1}$ Inan, Alföldi-Rosenbaum 1979, 300, no. 296, Pl. 270, 5-6; Firatl 1990, 16, no. 26, Pl. 12; Meischner 1997, 47, Pl. 15.8; Meischner 2001, 133-134, Figs. 387-390; Schade 2003, 225-226, I 65; Stichel 2005, 69; LSA 239.

${ }^{2}$ Prusac 2016a, 93-94, Sketch 3 a-b.

${ }^{3}$ Oberleitner 1959; Inan, Rosenbaum 1966, 155, no. 199, Pl. 186, 1-2; Sande 1975, 99-100, 103, Pl. XVII, Figs. 55-56; LSA 695.
} 
head in Venice, the so-called Carmagnola (presumably Justinian I). ${ }^{4}$ The latter appears to have been cut from a piece of porphyry which did not suffice for a nose of normal proportions. ${ }^{5}$ The face of the woman in Figs. 1-3 is tilted backwards to an extreme degree. It was probably done to save material at the back of the head, so that a rather complicated coiffure could be carved out. This is typical of female portraits, where the coiffure is often more important than the facial features.

At the back of the head the hair is combed into wedges on each side of a central parting. This is a variant of the so-called melon coiffure, which was popular during the Hellenistic period until the time of Augustus, when it was supplanted by the nodus coiffure. ${ }^{6}$ It continued in use as a coiffure for young girls, and in Late Antiquity it regained a certain popularity among older women, as well.

In the melon coiffure the single strands of hair run perpendicularly to the wedges. They do so in the case of "the Horrible Lady" also, but her sculptor has only rendered a few of them with deep incisions, giving the hair a checkered appearance. The hair at the front and the back is separated by a narrow strip which may either be a ribbon or a twisted strand of hair. Above the forehead and temples the hair is combed into thick, slightly wavy locks covering the ears. At the angle of the jaw the hair is combed back and gathered in a bun, into which the wedges of the melon coiffure must also have been incorporated. In the frontal view the hair forms a series of buckles framing the face.

These buckles are rather loose, and could be taken for the curls of a male portrait (compare FIG. 5). I have classified the portrait as female for two reasons. 1) Recarving of portraits across gender lines is extremely rare. ${ }^{7}$ 2) If it was meant to be a male portrait in its last version, the sculptor would not have taken the trouble to recut the hair into a female coiffure further back. As guidelines he must have had the coiffure of the original head, probably an Antonine portrait from Faustina Minor's mature period. ${ }^{8}$ The whole part has been recut to blend with the rest of the hair.

Because of the way the face is tilted backwards, its lower part is proportionally much larger than the upper one. The lady has a double chin and her cheeks are so broad that they almost seem inflated. These parts are carefully modelled, so the sculptor must have wanted to give a picture of a plump woman. Her mouth is tiny, its edges being in line with her broad, flat nose. These proportions also seem intentional. Above the nose there is little space available, and consequently the forehead becomes both low and narrow. The large, flat eyes with faint pouches underneath and incised irises are framed by thick eyelids. The inner and outer corners of the eyes are prolonged by incisions, as if the lady was wearing eyeliner.

As for the date of the portrait, Jale Inan and Elisabeth Rosenbaum, who published it, found it difficult to place. As they pointed out, the coiffure of the head does not correspond to

\footnotetext{
${ }^{4}$ Delbrück 1914; Volbach, Lafontaine Dosogne 1968, Fig. 105 (text: H.-G. Severin); Sande 1975, 97-100, 103, Pl. XVI, Figs. 51-52; Stichel 1982, 64-65; Del Bufalo 2010, 53, Fig. 85; Del Bufalo 2012, 110-111, H. 44.

${ }^{5}$ Severin and Stichel believe that the nose was cut down because of damage which the head may have suffered in the early $13^{\text {th }}$ century, but according to Del Buffalo, the nose is original. This is also my impression.

${ }^{6}$ For the nodus coiffure see Trillmich 1976, 59-64; Dillon 2010, 114-116.

${ }^{7}$ See Prusac 2016a, 112-113.

${ }^{8}$ Compare Fittschen, Zanker 1983, nos. 20-21, Pls. 28, 30 (Faustina), nos. 104-107, Pls. 131-135 (private portraits). Notice especially no. 107, where the plaits converge around a deep depression, almost a hole. This detail recurs on the "Horrible Lady's" bun.
} 
that of any known empress of the Late Antique and Early Byzantine period, and the authors concluded saying: "Eine nur versuchsweise Datierung des vorliegenden Porträts scheint unmöglich". In Nezih Frratlı's catalogue of the Late Antique and Byzantine sculpture in the Archaeological Museum of Istanbul (completed by Catherine Metzger, Anne Pralong and Jean-Pierre Sodini) the date is given as “...pas antérieure au VIe siècle. Elle peut même être plus tardive."

I would suggest a date in the first half of the sixth century. It is true that dating the hairdo is difficult because of the lack of Imperial models, but if one looks at the mosaic of Theodora and her court ladies in the church of San Vitale in Ravenna, one notices that the woman next to the empress wears a melon coiffure, its wedges clearly articulated. ${ }^{11}$ The locks in front are covered with a veil or a scarf, whereas they seem to have been visible in our portrait.

An early sixth century date was given by E. Schade in her book on Late Antique female portraiture. ${ }^{12}$ Following J. Meischner, she compared the "horrible lady" to a portrait in New York. ${ }^{13}$ Personally, I do not find the likeness between them very close. The two heads do have one thing in common: both are recut. The small curls articulated with drill holes above the forehead and in front of the ears of the New York head suggest that it was cut from a late Claudian or Neronian portrait. Further back on the head confusion begins. The sculptor seems to have tried to carve long strands of hair across the top of the head from ear to ear, but these strands peter out and give way to three tiers of hair rendered with sharp (modern?) chisel strokes at the back of the head. Higher up the hair is woven into two braids which form a "nest" with their ends curled up inside. This arrangement may be a substitute for the so-called Rundflechtfrisur (also called Zopfkranzfrisur), where one or two voluminous braids encircle the whole head, often ending in a ring-shaped bun. ${ }^{14}$ The Julio-Claudian head which served as material for the portrait in New York, was sufficient only for the bun.

Schade remarks that the face "wirkt überraschend lebendig". 15 The reason is that the late Antique sculptor limited himself to alter only the main features: eyes, nose and perhaps the mouth. Large areas of the Julio-Claudian face therefore remain: the cheeks, the forehead and the neck in front. The original head was not intended to be inserted, but must have formed part of a bust or statue. The late Antique sculptor cut it out from its setting as best he could. He was luckier (or more clever) than the sculptor of "the Horrible Lady". It is difficult to imagine how the latter portrait was mounted without being tilted too much forwards or backwards.

As a recut head, the New York portrait has few points to offer in support of a date. The deep hollows in the eyes, which comprise both iris and pupil, occur in portraits in the period

\footnotetext{
${ }^{9}$ Inan, Alföldi-Rosenbaum 1979, 300.

${ }^{10}$ Firatli 1990, 16.

${ }^{11}$ Deichmann 1958, Figs. 358, 360-362; Grabar 1967, Figs. 172-173; Bauer, Zimmermann 2001, 21, Fig. 10; Schade 2003, Pl. 21.2.

${ }^{12}$ Schade 2003, 226, following Meischner 1997, 47; Meischner 2001, 133-134.

${ }^{13}$ For the head in New York see Meischner 1997, 47, Pl. 15, Figs. 5-6; Meischner 2001, 133, Figs. 387-390; Schade 2003, 224-225, I 64, Pl. 65. 2-4; LSA 465.

${ }^{14}$ Compare Schade 2003, Pls. 26-32, 33.3-4, 38, 40-44, 48.

${ }^{15}$ Schade 2003, 225.
} 
between the late fourth/early fifth and the early sixth century. ${ }^{16}$ I would prefer to date the portrait to the beginning of this period. The subtly modelled flesh of the original portrait which was left after the recutting, would be in accordance with the tastes of the Theodosian period with its "subtle style". The sixth century sculptors, on the contrary, preferred faces characterized by abstract, stereometrical planes. I shall therefore in the following leave the New York portrait out of the discussion.

As comparative material for "the horrible lady" a recut male portrait found near Balıkesir in Western Turkey is more pertinent (FIG. 5). ${ }^{17}$ The portrait, now in the Archaeological Museum in Istanbul, has on account of its coiffure been dated to the first half of the sixth century AD. Like our portrait it has large, flat eyes with sharp incisions indicating the corners. A Medusa head on a sixth-century relief slab in the Byzantine Museum in Athens shows the same "eyeliner" effect. ${ }^{18}$

The checkered hair of "the horrible lady" recurs in a number of sixth century ivories, chiefly pyxides, but also diptychs. ${ }^{19}$ I would also direct attention to an ivory statuette in the Schloss Fasanerie in Fulda, Germany. ${ }^{20}$ It is hollow and may originally have carried something. According to its publisher, H. von Heinze, it represents a consul, but this is unlikely since it wears a pallium/palla. The round face and fat neck are in accordance with the pyknic ideals of $6^{\text {th }}$ century portraiture (compare FIGS. 1, 9 and 11). The figure could be both male or female. Its posture with the arms modestly hidden in the draperies echoes countless statues of women from the Hellenistic period onwards, though philosophers could also be represented like this. ${ }^{21}$ In the case of a philosopher, one would have expected a beard, however. The pronounced "Venus ring" on the throat of the statuette is a typically female feature. On the other hand, the checkered hair which uniformly covers the head is in accordance with male coiffures, though one might object that the ivory cylinder did not afford sufficient material to make an elaborate hairdo.

Despite its small size (h. $10.3 \mathrm{~cm})$, the bronze bust of a woman which decorated a table leg lends itself to a comparison with "the Horrible Lady". ${ }^{22}$ In addition to the large "eyeliner eyes" they share a decidedly fat face, but the hair of the bronze bust is covered. Only above the forehead is a small part of the hair revealed in the shape of a checkered strip. It is no surprise that portraits influenced miniature objects - it suffices to allude to the many decorative pins crowned with female busts. ${ }^{23}$ Not only are the outward signs such as the type of coiffure identical, both the large and small versions share the same esthetic principles.

\footnotetext{
${ }^{16}$ Compare Delbrück 1933, Pls. 93, 114, 127; Sande 1975, Pls. I-IV, VIII, IX, Fig. 31, X, XIV, XVI, fig. 51; Kiilerich 1993, Figs. 38-41, 45 a, 48-50, 66, 68; Schade 2003, Pls. 54.1,3, 56. 1, 60.2, 63.1-3, 65.2, 67.2.

${ }^{17}$ Sande 1975, 83-85, Pl. VII, Figs. 23-25; Inan, Alföldi-Rosenbaum 1979, 159-160, no. 112, Pl. 269,1-4; Firatl1 1990, 15-16, no. 25, pl. 12; Lenaghan 2016, 106, Fig. 8:1; LSA 412.

${ }^{18}$ Brenk 1978, 86, Pl. II b; Ensoli, La Rocca 2000, 644, no. 347 (text: N. Dimitrakopoulou-Skiloghianni).

${ }^{19}$ Diptychs and panels: Volbach 1976, nos. 8-11, Pls. 4-5, no. 48, Pl. 26, nos. 125-126, Pl. 66, no. 140, Pls. 73-74. Pyxides and other small scale works: Volbach 1976, no. 88 c, Pl. 49, no. 105, Pl. 56, no. 163, Pl. 83, nos. 165-168, Pls. 84-85, nos. 178-179, Pl. 90, no. 181, Pl. 91, no. 194, Pl. 96, no. 197, Pl. 97, no. 214, Pl. 100.

${ }^{20}$ Von Heinze 1986, 36-39, Pls. 10:1-4, 11:1-2. The author (rightly, in my opinion) compares it to consular diptychs of the early $6^{\text {th }}$ century, which, however, does not prevent her from dating it to the fifth century.

${ }^{21}$ See Fejfer 2008, 368, Fig. 307.

${ }^{22}$ Wamser 2004, 238-239, no. 355 (text: G. Zahlhaas).

${ }^{23}$ See for instance Fejfer 2008, Pl. 24; Wamser 2004, 278, no. 434 (text: J.G. Deckers).
} 
The word "esthetic" may seem a misnomer in regard to "the Horrible Lady". She has not met a favourable reception. The term "Horrible Lady" goes back to the late Nezih Firatl, who in his catalogue described its features as "caricaturaux". ${ }^{24}$ According to J. Inan and E. Rosenbaum the portrait represents "eine sehr hässliche Frau". ${ }^{25} \mathrm{~K}$. Schade remarks that the face is "auf geradezu bizarre Weise aufgedunsen", ${ }^{26}$ and J. Meischner speaks about "Basedowaugen". ${ }^{27}$ The woman portrayed is certainly no beauty, but I think that the negative reactions to her have a gender aspect. She is a woman, and women are supposed to be beautiful. However, are the male portraits from the $5^{\text {th }}-6^{\text {th }}$ centuries (especially the recut ones) more handsome?

Yet none of the male portraits in J. Inan and E. Alföldi-Rosenbaum's catalogues is called "ugly" (FIGS. 4-7). At most they are described as "provincial", with "carving of rather poor quality", or showing "an ornamental version" of their features. ${ }^{28}$ A portrait from Sardes, which went by the nickname of "Sourpuss" (coined by its publisher, George Hanfmann), is described as showing "ausgeprägte Individualität". ${ }^{29}$

One of the factors which make "the Horrible Lady" unattractive, is no doubt her obesity. For men and women of our age the word has negative connotations: poverty, junk food and lack of self-control. We prefer the narrow face of the empress Theodora, preserved in the famous mosaic in Ravenna, and probably also in a head in Milan (FIG. 8). ${ }^{30}$ To most people this is the Justinian female face.

But one need not go further back than to Theodora's predecessor, the empress Eufemia, to see a different ideal. She is probably represented in a bronze head in the museum of Niš. ${ }^{31}$ The head is without personal features, and the identification is dependent on the findspot, Balajnac, in an area where Eufemia's husband Justin I was born (and probably Eufemia as well). The woman wears the typical head-covering of $6^{\text {th }}$ century empresses, and she has a round, plump face with a faint double chin.

The so-called Ariadne (or the Gothic queen Amalasuntha, according to others) in the Musei Capitolini in Rome (FIGS. 9-10), ${ }^{32}$ and her two "sisters" (FIG. 11) ${ }^{33}$ (or do they represent the same woman?) in the Museum of the Lateran Basilica and the Louvre respectively

\footnotetext{
${ }^{24}$ Firatli 1990, 16.

${ }^{25}$ Inan, Alföldi-Rosenbaum 1979, 300.

${ }^{26}$ Schade 2003, 225.

${ }^{27}$ Meischner 1997, 47; Meischner 2001, 134.

${ }^{28}$ Inan, Alföldi-Rosenbaum 1979, 160 (under no. 112); Inan, Rosenbaum 1966, 155 (under no. 199), 151 (under no. 193).

${ }^{29}$ Inan, Alföldi-Rosenbaum 1979, 201 (under no. 171).

${ }^{30}$ Delbrück 1913, 310-318, 326, 349-352, Figs. 1 a, 1 b, 4, Pls. 9-10; Sande 1975, 93-97, Pl. XIV, Figs. 46-48 (with bibliography); Stichel 1982, 63-64, Pl. 33; Schade 2003, 227-228, I 67, Pl. 67.2-4; Fejfer 2008, 350-351, Fig. 273; Schade 2016, 256-257, Fig. 20.10; LSA 760.

${ }^{31}$ Srejovič, Simovič 1958-1959, Figs. 3-6; Sande 1975, 96-98, Pl. XV, Figs. 49-50; Weitzmann 1979, 32 , no. 26 (text: J.D. Breckenridge); Stichel 1982, 63, Pl. 32; Schade 2003, 218-219, Pl. 62; LSA 759.

${ }^{32}$ Delbrück 1933, 313, 323-326, 349-352, Pls. 14-15; Sande 1975, 67-79, Pl. IV Figs. 13-14; Stichel 1982, 59-61, Pls. 26, 28; Fittschen, Zanker 1983, 36-38, no. 39, Pls. 49-50 (with bibliography); Ensoli, La Rocca 2000, 581-582, no. 269 (text: M. Bergmann); Schade 2003, 219-220, I 60, Pls. 63:1, 64:1-2; Prusac 2016b, 172-173, no. 3; LSA 756.

${ }^{33}$ Delbrück 1913, 318-322, 324-326, 349-352, Fig. 5, Pls. 11-12, 16-17; Sande 1975, 67-79, Pls. III, Figs. 9-11, IV, Fig. 12; Weitzmann 1979, 30-31, no. 24 (text: J. D. Breckenridge); Stichel 1982, 59-61, Pl. 25; Fittschen, Zanker 1983, 37; Ensoli, La Rocca 2000, 582-583, nos. 270-271 (text: M. Bergmann); Schade 2003, 220-224, I 61-I 62, Pls. 63: 2-4, 64: 3 4; Prusac 2016b, 174-177, nos. 3-4; LSA 755 (Lateran) and 757 (Louvre).
} 
are probably a little earlier than Eufemia. All three (especially the head in the Musei Capitolini) are decidedly plump with a marked double chin. In the Capitolini head the spherical ideal is particularly clear, the height of the face more or less equaling the breadth, as it does in in the head of "the Horrible Lady". In all these portraits the upper part of the face takes up a remarkably small space compared to the lower part, with a very low forehead and curved, hairless eyebrows. The eyes are large and staring with bags of flesh underneath, and the upper eyelid ends well beyond the outer corner of the eye.

The Ariadne-Amalasuntha type or similar imperial portraits erected in Constantinople and the provinces have clearly inspired "the Horrible Lady's" sculptor. The woman displays a general plumpness of the face, large, staring eyes with bags of flesh underneath, hairless eyebrows and a small mouth. The "eyeliner effect" may be an attempt to reproduce the drawnout upper eyelid (a feature also found in the portrait of Theodora in Milan). The "AriadneAmalasuntha" heads are not recut portraits, and their sculptors therefore had the necessary material at their disposition, as opposed to the sculptor of "the Horrible Lady". He had to tilt the face back and incise the features rather than carve them. Still, he has managed to copy the most salient points of his models.

"The Horrible Lady" is therefore not as crude and unsophisticated as she may seem at first glance, since the plump ideal which her sculptor aimed at, was well established in the $6^{\text {th }}$ century. ${ }^{34}$ Also male portraits of the period are fleshy, and Justinian himself is in his mosaic panel in Ravenna is rather florid, in accordance with Procopius' description of him. It would seem that a florid aspect was seen as an ideal, and that the sallow-skinned, narrow-faced Theodora was more of an exception.

Among non-imperial images several of the consular diptychs of the $6^{\text {th }}$ century show decidedly round faces with hairdos to match. ${ }^{35}$ The more or less spherical form is an ideal. The plumpness probably stands for abundance and wealth, suitable for the figure of the consul as the provider of gifts to the people.

In female portraiture the fleshy face has a long tradition as a sign of matronal values. ${ }^{36}$ The Ariadne-Amalsuntha type constitutes a throw-back to the Theodosian period. As an example may be mentioned a female bust in Thessaloniki with a plump face, large, protruding eyes under arched, hairless brows, and a low, narrow forehead (FIG. 12). ${ }^{37}$ Even more striking is the resemblance between Ariadne-Amalasuntha and a female portrait head recently found in Athens, dated to the late fourth or early fifth century. ${ }^{38}$ There we see the features of Ariadne-Amalasuntha in a softened version. In the sixth-century portraits these features are hard-

\footnotetext{
${ }^{34}$ As J. Meischner remarks, "dieser pyknische Typ war das Modegeschicht der Epoche” (Meischner 2001, 133). According to her, the recut portrait in New York (n. 8) represents "biedermeierische Charme" (Meischner 2001, 133). She also writes that certain private portraits are "von erstaunlich bürgerlichem, biedermeierischem Charakter" (Meischner 2001, 138). However, as R. Stichel has pointed out, the persons who were able to order a portrait statue made in the 6th century, were far from "bürgerlich", but belonged to the upper social stratum (Stichel 2005, 69).

${ }^{35}$ Volbach 1976, 32-38, nos. 8-24, Pls. 4-10.

${ }^{36}$ Schade 2003, 182, 207.

${ }^{37}$ L'Orange 1961, 68-73, Pl. 27: 2,4; Kiilerich 1993, 120-121, Fig. 61; Kiilerich 2008, Figs. 24.1, 24.5; Schade 2003, 206-207, I 47, Pl. 55:1; Schade 2016, 253, Fig. 20.4; LSA 91. It was found together with a male bust: L'Orange 1961, 68-74, Pl. 27: 1,3; Kiilerich 1993, 113, Fig. 62; Kiilerich 2008, Figs. 24.224.10; Schade 2003, 207, Pl. 55:2; Smith 2016, 21, Fig. 1.19; Bergmann, Kovacs 2016, 290-291, Fig. 23.20; LSA 90.

${ }^{38}$ Gehn 2016, 197, Fig. 15.3; LSA 2693. It was found together with another female portrait head, which on account of its extreme narrowness must be recut (Gehn 2016, 197, Fig. 15.4; LSA 2694).
} 
ened to more abstract forms. The underlying geometric form (the sphere) is also less pronounced in the Athenian portrait, which has a face with normal proportions.

The Athenian head was found during construction of the new Acropolis Museum in the ruins of a house, and was evidently a private portrait. As far as I know, there is no evidence for private sculpted portraits as late as the sixth century. "The Horrible Lady" is therefore probably a publicly displayed portrait. It was purchased in Istanbul, but is unlikely to have been found there. All evidence concerning the display of portraits in Constantinople points to a strictly controlled patronage of statues. The city prefects seem to have been responsible for most of them. ${ }^{39}$ Statues of members of the Imperial families dominate, along with those of generals and high civil servants. There is no place for a non-imperial woman here, though it should be remembered that monuments to some very low-ranking persons were displayed in sixth-century Constantinople: the statues of charioteers on the hippodrome. However, these were erected by the circus factions. ${ }^{40}$

While imperial portraits made up the bulk of statues in the capital, prominent locals dominated in the provinces, and it is there one can imagine a public monument to a woman. She would have been a benefactress, a person who contributed to the common good of the community. There is evidence for female euergetism in Asia Minor. The most famous example is Plancia Magna from Perge, whose portrait statue is on display in the Museum of Antalya. ${ }^{41}$ There were lesser-known women portrayed in Perge and elsewhere.

Among Late Antique monuments the statue of Scholasticia springs to mind. ${ }^{42}$ A seated statue of her was erected in the late fourth or the fifth century as a sign of gratitude for her restoration of the Baths of Varius. The statue, which was found headless, was published by F. Miltner as a Theodosian work, but in an article from 1985 V. M. Strocka declared it to be a reused statue from the second century. ${ }^{43}$ Strocka compared it to a funerary statue of a seated woman in the museum of Tire, forty kilometers from Ephesos, which he on stylistic grounds dated to the second century. The strength of Strocka's argument depends on whether his dating of the Tire statue is correct. One could always turn the argumentation around and say that since the Scholasticia statue was erected in the Theodosian period, the Tire statue could be Theodosian, too. This shows how difficult it often is to decide if a sculpture is a second century or a fourth-century piece of work.

For my argument it is of little importance whether the Scholasticia statue is a Theodosian original or if it is a reused work, as is its base. The important thing is that this statue was erected to a woman. Scholasticia did not lack female role models for her building activities, for the Theodosian empresses were builders. Aelia Eudoxia, wife of Aradius, funded the famous basilica in Gaza, ${ }^{44}$ while her daughter Pulcheria and her daughter-in-law Eudocia are

\footnotetext{
${ }^{39}$ For Late Antique statues in Constantinople see Bassett 2014; Gehn, Ward-Perkins 2016.

${ }^{40}$ For statues of charioteers see Cameron 1973; Firatl1 1990, 30-34, nos. 63-64, Pls. 23-24; Bauer 2007, 103-105, Figs. 10-12.

${ }^{41}$ Inan, Alföldi-Rosenbaum 1979, 248, no. 225, Pls. 158, 1-3, 159, 160, 2, 271, 4; Dillon 2010, 156-159, Fig. 80; Fejfer 2008, 363-369, Figs. 302, 308. For Plancia Magna's activities see Boatwright 1991.

${ }^{42}$ Miltner 1956, Beiblatt, 22-26, Fig. 15; Schade 2003, 240, II 90, Pl. 10.2; Auinger, Sokolicek 2016, 161, Fig. 13.1; LSA 741, 472.

${ }^{43}$ Strocka 1985. He claims that Scholasticia holds a mappa. That is not correct. She holds an instrument, probably a kind of compass, an instrument suitable for a person involved in building activities.

${ }^{44}$ Holum 1982, 56; Angelova 2015, 223-224.
} 
credited with building on a larger scale. ${ }^{45}$ During her stay in the Holy Land, Eudocia did not only finance churches and hostels for pilgrims and the poor, she also restored the walls of Jerusalem and added fortifications to encompass Mount Sion within the enceinte. ${ }^{46}$ Galla Placidia built a church to St. John the Evangelist in Ravenna, where she also embellished other churches, and she restored S. Paolo fuori le Mura in Rome. ${ }^{47}$ The names of Theodosian empresses were also associated with baths, but it is not always clear whether they financed the building activities themselves, or whether it was done by a male relative in their name. ${ }^{48}$

The existence of such role models would no doubt have made it easier for non-imperial women to employ their wealth to construct or reconstruct buildings for the common good. The Theodosian period was a time of visibility for women, which is also reflected in the comparatively large number of female portraits. After the middle of the fifth century their number dwindles rapidly.

The sixth century saw new examples of female building activity, embodied in the figure of Juliana Anicia, the builder of the church of S. Polyeuctos in Constantinople. In a long carved inscription inside the church, recorded in the Antologia Palatina, Juliana Anicia refers back to the Theodosian period and the empress Eudocia. ${ }^{49}$ According to the inscription, she shared the royal blood with Eudocia in the fourth generation. Literate visitors to S. Polyeuctos were thus reminded of its constructor's imperial lineage. The Dioscurides manuscript in Vienna, which shows a painted portrait of Juliana Anicia, is a gift from the people of Honoratai, a suburb of Constantinople, in gratitude for her having funded a church. ${ }^{50}$ Juliana Anicia's name is also connected with a church for S. Euphemia, and possibly one for S.Stephen. ${ }^{51}$

The empress Theodora is also credited with building activity. She constructed a church in Antioch, and together with Justinian she figures as a co-builder of some of Constantinople's most prestigious churches: Hagia Sophia, Hagia Eirene and SS. Sergius and Bacchus. Alone or together with Justinian she built homes for old people, orphanages, hospitals, hospices, baths and other buildings with a social function, such as the famous monastery for former prostitutes called "Repentence". Her name figures with that of Justinian on city walls and military structures, several fortresses in the provinces bore her name, as did the baths in Carthage. ${ }^{52}$ To what extent she was personally involved in this building activity we do not know, but the presence of her name or monogram in or on a number of public buildings will have made her appear as a builder and a benefactress, and thus a model for women to emulate. This would probably have been easier to emulate in the provinces, where there was a tradition of female euergetism.

I believe that "The Horrible Lady" portrays a sixth-century benefactress from a town in Western Asia Minor (in the Eastern part the production of portrait sculpture had already ceased). The head may have come to light during building or agricultural works. There would

\footnotetext{
${ }^{45}$ For Pulcheria see especially Angelova 2014.

${ }^{46}$ Holum 1982, 219.

${ }^{47}$ Angelova 2015, 224-225.

${ }^{48}$ Angelova 2015, 173-180.

${ }^{49}$ Harrison 1989, 33; Kiilerich 2001, 181-182; Angelova 2015, 229-232.

${ }^{50}$ Harrison 1989, Fig. 32; Bauer, Zimmermann 2001, 13, Fig. 29, 46, Fig. 3; Kiilerich 2001, Fig. 1; Schade 2003, 245, III 10, Pl. 14.2; Angelova 2015, 226-229, Figs. 117-118.

${ }^{51}$ Kiilerich 2001, 181; Angelova 2015, 232.

${ }^{52}$ For building activities connected with Theodora's name see Ravegnani 2016, 64-67, 150.
} 
have been no point of selling it locally, for even if the area was frequented by tourists, these would at most only buy smaller objects like lamps or coins. Therefore it would have been natural for the discoverers of the head to bring it to Istanbul to be sold, presumably through an antiquarian, of whom there were a certain number in the 1960 's. The "provincial" style ${ }^{53}$ of the portrait also speaks for a findspot outside the Capital, though one could perhaps have chosen a more precise term than "provincial". Scholars often employ it when they speak about works which fall below their expectations, and consequently it becomes more a question of quality than provenance.

Finally, one may ask why the lady, if she lived in the 6th century, did not present herself with her hair covered. Already by the end of the fourth century it became fashionable for women to cover their hair. ${ }^{54}$ As parallels to the "Horrible Lady" I have therefore used portrait sculptures with and without covered hair from the end of the 4th to the middle of the 5th century, though they are considerably earlier. Their coiffures, which occur in other medias such as mosaics (see below) throughout the fifth and well into the sixth century, are remarkably stable, and do not suggest sudden changes of fashion.

It seems that the covered head often represented married status, while the uncovered head represented unmarried state, that is, virginity. Thus on the triumphal arch in S. Maria Maggiore in Rome the Virgin Mary is represented as a young princess with uncovered head, even after her marriage to Joseph. ${ }^{55}$ In the mosaics in the nave of the same church, Rachel is shown with uncovered head up to her wedding with Jacob, a thin veil covering the back of her head in the marriage scene. ${ }^{56}$ In the scene showing Jacob returning to Lea, Rachel and their children, both sisters have their heads covered. ${ }^{57}$ Only the colour of their dress distinguishes them. Rachel is dressed in red, as she is in the scenes that portray her as a young virgin, Lea is in blue. Lea is always represented with her head covered, which would seem to contradict the virgin/matron scheme, but this is probably deliberate. In the first scene showing the two sisters with their father Laban, Lea's covered head may be a means to indicate that her father sees her and not Rachel as Jacob's spouse. The head-cloth may have also been included to give Lea a stodgy, matronly aspect in contrast to her younger and more attractive sister.

In the $5^{\text {th }}$ century Lord Julius mosaic from Carthage, which shows life in the countryside, both the domina and her servants show their hair. ${ }^{58}$ The $5^{\text {th }}$ century mosaic from Sidi Ghirb, on the other hand, depicts bare-headed servants and the domina with covered hair. ${ }^{59}$ She is wearing a pale blue bonnet with the hair below forming a roll decorated with pale blue and golden-brown stripes. Serena (?) on the so-called Stilico diptych in Monza wears the same combination of bonnet and hair roll, both covered with a striped fabric. ${ }^{60}$

\footnotetext{
53 "Provincial": Inan, Alföldi-Rosenbaum 1979, 300 (under no. 296); Meischner 1997, 47; Meischner 2001, 134.

${ }^{54}$ Schade 2003, 116.

${ }^{55}$ Karpp 1966, Pls. 6, 13; Wilpert, Schumacher 1976, Pls. 51-55, 61-63, 64-66.

${ }^{56}$ Karpp 1966, 49, 56, 61; Wilpert, Schumacher 1976, Pls. 31 b, 32 a-b.

${ }^{57}$ Karpp 1966, Pl. 72; Wilpert, Schumacher 1976, Pl. 34.

${ }^{58}$ Dunbabin 1978, 119-121, Pl. 43, Fig. 109; Weitzmann 1979, 271, Fig. 32; Bauer, Zimmermann 2001, 112, Fig. 35; Schade 2003, 246, III 12, P1. 18.3.

${ }^{59}$ Bauer, Zimmermann 2001, 25, Fig. 15, 114, Fig. 38; Schade 2003, 245-246, III 13, frontiscpice; Ben Abed 2006, 42, Figs. 21 A-21 B; Schade 2016, 253-254, Fig. 20.5.

${ }^{60}$ Volbach 1976, 55-56, no. 63, Pl. 35; Kiilerich, Torp 1989; Kiilerich 1993, 137-141, Figs. 78-79; Schade 2003, 244, III 3, Pl. 15.2; Schade 2016, 254-255, Fig. 20.6. The same type of striped bonnet is worn by a shepherdess on a silver plate in Berlin (see note 71).
} 
Female portraits in the round from the late $4^{\text {th }}$ and $5^{\text {th }}$ centuries present the same alternation between covered and uncovered head. A bust in New York, heads in Copenhagen, Toulouse, and Bonn and a bust in Bodrum all wear a bonnet. ${ }^{61}$ The Bodrum bust was found together with a male bust which in all likelihood represents her husband, ${ }^{62}$ and would therefore seem to confirm the combination of married status/covered head. However, the female bust in Thessaloniki mentioned above (FIG. 12), which is also one of a pair, has its head uncovered. ${ }^{63}$ The woman wears a Scheitelzopffrisur, which was developed in the $3^{\text {rd }}$ century. It is incompatible with wearing a bonnet, which has consequently been left out. By choosing a Scheitelzopffrisur the woman may have wanted to demonstrate adherence to traditional values.

It would seem that not only civil status, but also the type of coiffure determined the presence or absence of a bonnet. The Rundzopffrisur was ideal for being covered with a bonnet or wrapped in a scarf or hairnet. Still, there are several examples of Late Antique portraits with uncovered Rundzopffrisur. ${ }^{64}$ Since several, if not the majority, of these portraits appear to be recut from $2^{\text {nd }}$ and $3^{\text {rd }}$ century heads, the coiffure of the original head may have determined the choice of the Late Antique sculptor.

Theodosian court etiquette required that women presented themselves with uncovered heads in the Imperial presence. ${ }^{65}$ Consequently all the ladies reveal their hair in the mosaic panel in S. Maria Maggiore showing Moses at Pharao's court. ${ }^{66}$ A statuette in the Bibliothèque Nationale in Paris, often called Aelia Flacilla, is bare-headed apart from the diadem. ${ }^{67}$ She wears a traditional Scheitelzopffrisur, as do the Theodosian empresses in their coin portraits. Around the middle of the $5^{\text {th }}$ century a new coin image of the empress emerges. Some of the coins of Licinia Eudoxia (439-455) show her with two triangular figures on top of her head, probably meant to represent a hair covering similar to that of Theodora in the mosaic in Ravenna. ${ }^{68}$ Two ivory diptychs in Florence and Vienna probably representing Ariadne, and a number of portraits in the round give a more softened version of this headgear, in the shape of a stiff bonnet with a "dip" in the middle. ${ }^{69}$

By the $6^{\text {th }}$ century a covered head seems to have become the rule for female portraits. Turturra in a wall-painting in the catacombs of S. Domitilla in Rome has her head covered by a black palla, over which she wears a wreath. ${ }^{70}$ The Virgin Mary in the same painting has in addition to the palla a piece of white fabric covering the Rundflecht which frames her face. The same combination is sported by Hilarias in a wall painting in the catacombs of S. Gen-

\footnotetext{
${ }^{61}$ Schade 2003, I 40, Pl. 49.1-2, I 46, Pl. 54.3-4, Pl. 55.3-4, I 49, Pl. 56, I 50, Pl. 57, I 52, Pl. 58.3-4, 59.1-3.

${ }^{62}$ Kiilerich 1993, 113-115, Fig. 63; Kiilerich 2008, Figs. 24.4, 24.11; Schade 2003, 212-213 (under I 52) P1. 58.4; Smith 2016, 10-11, Fig. 1.9; Bergmann, Kovacs 2016, 291-292, Fig. 23.21.

${ }^{63}$ See n. 37.

${ }^{64}$ See Schade 2003, Pls. 36-38, 40-44, 48, 52-53.

${ }^{65}$ Clark 2008, 115.

${ }^{66}$ Karpp 1966, Pl. 85; Wilpert, Schumacher 1976, Pl. 37; Schade 2003, Pl. 13.1.

${ }^{67}$ Delbrück 1933, 163-165, Pls. 62-64; L'Orange 1961, 72-73, Pl. 30, 5-7; Stichel 1982, 52-53, P1. 19; Kiilerich 1993, 96-98, Figs. 44-45; Schade 2003, 204-206, I 46, Pl. 54.1-2; Fejfer 2008, 350, Figs. 270-271; Schade 2016, 255-256, Fig. 20.8; LSA 568.

${ }^{68}$ Delbrück 1933, P. 24, Licinia Eudoxia 6. For Theodora see note 11.

${ }^{69}$ Delbrück 1913, 341-342, Figs. 14, 16; Volbach 1976, 49-50, nos. 51-52, Pl. 27; Weitzmann 1979, 31-32, no. 25 (text: J.D. Breckenridge); Ensoli, La Rocca 2000, 580-581 (text: K.S. Painter); Schade 2003, 244, III,4, P1. 13.3-4; Schade 2016, 256, Fig. 20.9.

${ }^{70}$ Grabar 1967, 167, Fig. 176; Bauer, Zimmermann 2001, 16, Fig. 36; Schade 2003, 245, III, 9, P1. $20: 2$.
} 
naro in Naples, ${ }^{71}$ as well as two benefactresses in a mosaic from the church of Kissufim in the Negev from the year 576/78). ${ }^{72}$ In the mosaic "the Lady of Silthous" (wife? mother?) is seen scattering coins while clutching an orarium, a handkerchief denoting high birth. The other woman, Kalliora, who offers a bird on a platter, is more modest-looking (her name may denote servile origins). ${ }^{73}$ There were, however, exceptions to the rule of covered hair for women: Georgia, wife of the paramonarius Theodore in a mosaic in the church of SS. Cosmas and Damianus in Gerasa from 533, is represented bare-headed. ${ }^{74}$

Also females in narrative Late Antique contexts display an alternation of covered and visible hair. Four Coptic woven roundels in New York featuring bucolic motifs evidently reflect popular models, probably spread through manuscripts. ${ }^{75}$ Some of the figures are found in other media. A squatting woman breastfeeding her child in one of the roundels recurs in a floor mosaic in the church of S. Stephen at Horvat Be'er-Shem'a. ${ }^{76}$ In both cases the head of the woman is covered. A walking shepherdess in another roundel is paralleled in the decoration of a silver plate, now in Berlin. ${ }^{77}$ The latter has her hair covered, while the woman in the roundel is bare-headed.

However, the choice was not only between completely covered and completely uncovered hair. In the miniature portrait of Juliana Anicia in the Vienna Dioscurides, Anicia is seen flanked by two female personifications, Megalopsychia and Phronesis. ${ }^{78}$ Both wear their dark hair fully visible according to Classical tradition. Anicia wears a red bonnet reminiscent of that worn by contemporary imperial women, but above her forehead a dark strip is visible. Since dark colours denoted poverty, this is hardly a piece of fabric, but more probably Anicia's hair.

It seems that few women could desist from letting small locks escape from under their head-scarfs or bonnets. This applies to the Theodosian head in Toulouse and the bust in Bodrum. The Ariadne-Amalasuntha portrait (FIGS. 9-10) displays two small locks above her forehead, as a continuation of the row of pearls and jewels above. ${ }^{79}$ The Lateran (FIG. 11) and Louvre replicas let some of their hair escape at the back of her head as well. ${ }^{80}$ The bronze had of Euphemia (?) displays a tiny lock in front of each ear, as does the severe Kalliora in the mosaic in the church at Kissifum.

Other combinations of covered/uncovered hair show larger sections of hair. A portrait head of a $5^{\text {th }}$ century empress in the Museo del Alto Medioevo in Rome has the hair in front

\footnotetext{
${ }^{71}$ Schade 2003, 245, III, 8, Colour Plate A.

${ }^{72}$ Schade 2003, 246, III, 15, Pl. 14:3; Talgam 2014, 236-237, Fig. 319.

${ }^{73}$ Both Schade and Talgam suggest that Kalliora is a personification. However, female personifications in Late Antique mosaics are always represented as young, beautiful women, and Kalliora is definitively old, with a thin, furrowed face.

${ }^{74}$ Piccirillo 1981, 37, 40-41, Fig. 27, P1. 30: Piccirillo 1993, 276-277, Fig. 509; Schade 2003, 246, III, 14.

${ }^{75}$ Weitzmann 1979, 249-251, nos. 227-230 (text: J. Weitzmann-Fiedler).

${ }^{76}$ Compare Weitzmann 1979, no. 227 with Talgam 2014, 197, Fig. 286.

${ }^{77}$ Compare Weitzmann 1979, no. 229 with Weitzmann 1979, no. 231, 251-252.

${ }^{78}$ See n. 50.

${ }^{79}$ The locks appear as small roundels. In the Musei Capitolini head they are flatter than the pearls on the bonnet, so they are likely to be hair (see Delbrück 1913, 321, 324-325.

${ }^{80}$ Delbrück 1913, Ps. 13 a, 17 b. On the head in the Musei Capitolini the back of the head is broken off up to the edge of the bonnet, so it is impossible to see if a tongue of hair was visible. See Fittschen, Zanker 1983, Pl. 50, top.
} 
combed into a series of u-shaped tongues (FIGS. 13-14). ${ }^{81}$ At the back the hair is taken into a Rundflechct, which, apart from a thin, twisted roll above the tongues, gives the appearance of an amorphous mass. That part of the coiffure was evidently covered with a piece of fabric, onto which the diadem was fastened. For the rest, the single strands of hair are carefully rendered, even on the top of the head, indicating that the hair was visible, at most covered with a thin net. The 6th century imperial head the Castello Sforzesco in Milan, commonly identified with Theodora, has the diadem fastened to a stiff bonnet (FIG. 8). ${ }^{82}$ It wears the same type of tongue-shaped coiffure as the empress in Rome. If it was covered, the fabric (most probably a net) must have been so thin that one could clearly see the single tongues of hair.

In the Catacombs of San Gennaro in Naples a female portrait in an arcosolium tomb recently came to light. ${ }^{83}$ The painting, which has been dated to the sixth century, shows the bust of an orans named Cerula. The back of her head, which is surmounted by a crux monogrammata, is covered by a veil, while the hair in front has the same tounge-shaped arrangement as that of the two empresses referred to in the previous paragraph. The hair is painted grey, an unusual choice for women. In a Christian funerary context the grey hair may denote the respect which old age commands, or it can be seen as lack of vanity. The latter assumption is, however, contrasted by Cerula's elegant shawl which is decorated with human figures, surely an expensive garment. It recalls the decorated dresses of Theodora and her court ladies in the mosaic of San Vitale. As remarked above, the woman next to Theodora has part of her hair combed into buckles. It is covered with a silvery material which may actually be a net of silver thread covering greying hair (the woman is no longer young, as indicated by her thin, pointed face). Cerula's hair may also have been covered with a net.

In Roman portraiture hairnets are rarely seen, and yet they must often have been employed to contain the complicated coiffures. In an article about Roman female hairstyles E. Bartman remarked that sculpted portraits practically never show remedies used to control the hair, such as pins, though these have been found in large quantities in female burials. ${ }^{84}$ Hairnets are also rarely seen apart from decorative specimens in metal. Bartman illustrates one example of a hairnet. It is worn by a second century bronze head in the Art Museum of Princeton University, and a real net has been used in the casting process. ${ }^{85}$ The meshes are so tight that the net almost amounts to a bonnet, and like the bonneted Late Antique ladies, the Princeton woman reveals a small part of her hair in front of each ear.

To control the thick, loosely plaited Rundflecht of Late Antiquity, a bonnet, scarf or net would often have been necessary. A bronze portrait in Bonn shows a thin, incised crisscross pattern on the top of the head, probably a means to render a very fine net. ${ }^{86}$ The Rundflecht of the portrait is enveloped in crisscross bands fastened with metal studs. This arrangement may have been sufficient to contain the hair, but in addition the hair may have been covered by an

\footnotetext{
${ }^{81}$ L'Orange 1962, Pls. 1,3,4; Ensoli, La Rocca 2000, 578, no. 262 (text: M. Bergmann); Schade 2003, 215-216, I 55, Pl. 60, 2-4; Prusac 2016b, 168-169, no. 1; LSA 406.

${ }^{82}$ See n. 30.

${ }^{83}$ Carandini et al., 23 with ill.

${ }^{84}$ Bartman 2001, 13-14, Fig. 10. Stephens 2008, 117, n. 27, mentions three examples of Roman female portrait sculptures with hairpins (bodkins) indicated. According to Stephens, the scarcity of bodkins encountered in Roman female portraiture is due to the fact that they were not much used (Stephens 2008, 119, 132).

${ }^{85}$ Bartman 2001, 14, Pl. 2.

${ }^{86}$ Schade 2003, 207-208, I, 48, Pls. 54. 3-4, 55. 3-4.
} 
extremely fine net like the one on top of the head. A simplified arrangement is seen in a mosaic from Tabarka showing a seated woman with a distaff. Her brown hair is enveloped in a series of bands, possibly with a thin net beneath. ${ }^{87}$

The widespread use of hairnets is illustrated by a remark by St. Augustine. He tells his sister's community of nuns that their heads should be covered, but not with something so thin as to show their hairnets. ${ }^{88}$ To St. Augustine hairnets equaled hair, probably because one could see the hair through the meshes.

Our portrait may have had a hairnet painted on its head, but it may equally well have been represented without one. The coiffure would in any case have conveyed the idea of cultus, which was embodied in hair that was contained and disciplined in braids, buns and waves undulated with curling iron. ${ }^{89}$

"The Horrible Lady" stands in a long tradition of female representations which interpreted cultus through hairstyles - the more complicated, the better. The woman's family and those who allowed her portrait statue to be erected, were certainly a highly conservative group which wanted to display a traditional image of a Roman elite woman.

An uncovered head in a period when women generally covered their hair, would have contributed to the woman's “otherness". Since women had no place in public life, their portrait statues emphasized their absence by showing them as different as possible from their real selves. ${ }^{90}$ The statue bodies were never their own, but copies of Greek statue types which conveyed female values such as beauty and modesty. "The Horrible Lady's" head was surely inserted into such a statue body, originally belonging to another portrait. Reuse was the rule rather than the exception in Late Antiquity.

In the facial features of female portraits idealization was often preferred to individualization. ${ }^{91}$ As we have seen, "the Horrible Lady's" sculptor tried to adhere to the pyknic type which was the contemporary ideal of the early $6^{\text {th }}$ century. In all its exaggeration our portrait is a late witness to a genre which was soon to disappear: the Roman public portrait statue.

siri.sande@roma.uio.no

\footnotetext{
${ }^{87}$ Fradier 1976, n. p. but on p. 14; Dunbabin 1978, 122, 271, Tabraka I, i.

${ }^{88}$ Clark 2008, 108.

${ }^{89}$ Fejfer 2008, 345.

${ }^{90}$ Fejfer 2008, 335-345; Dillon 2010, 60-102.

${ }^{91}$ Fejfer 2008, 351.
} 


\section{BIBLIOGRAPHY}

Andaloro, M., Bordi, G. (eds.) 2000: Santa Maria Antiqua tra Roma e Bisanzio, Milano.

Angelova, D.N. 2014: "Stamp of Power. The Life and Afterlife of Pulcheria's Buildings", in L. Jones (ed.), Byzantine Images and their Afterlives: Essays in Honor of Annemarie Weyl Carr, Farnham.

Angelova, D.N. 2015: Sacred Founders. Women, Men and Gods in the Discourse of Imperial Founding, Rome through Early Byzantium, Oakland (California).

Auinger, J., Sokolicek, A. 2016: "Ephesus", in Smith, Ward-Perkins 2016, 160-173.

Bartman, E. 2001: "Hair and the Artifice of Roman Female Adornment", AJA 105, 1-25.

Basset, S. 2014: "Late Antique Honorific Sculpture in Constantinople", in S. Birk, T.M. Kristensen, B. Poulsen (eds.), Using Images in Late Antiquity, Oxford and Philadelphia, 78-95.

Bauer, F.A. 2007, "Virtuelle Statuensammlungen", in F.A. Bauer, C. Witschel (eds.), Statuen in der Spätantike, Wiesbaden, 79-109.

Bauer, F.A., Zimmermann, M. 2001: Epochenwandel? Kunst und Kultur zwischen Antike und Mittelalter, Mainz.

Ben Abed, A. (ed.) 2006: Stories in Stone. Conserving Mosaics of Roman Africa, Los Angeles.

Bergmann, M., Kovacs, M. 2016: "Portrait Styles", in Smith, Ward-Perkins 2016, 280-294.

Boatwright, M.T. 1991: "Plancia Magna of Perge: Women's Roles and Status in Roman Asia Minor", in S.B. Pomeroy (ed.), Women's History and Ancient History, Chapel Hill, 249-272.

Bouzek, J., Ondrejová, I. (eds.) 1997: Roman Portraits, Artistic and Literary. Acts of the Third International Conference on the Roman Portraits held in Prague and in the Bechyne Castle from 25 to 29 September1989, Mainz.

Brenk, B. 1978: "Byzantinische Marmorschranken in amerikanischen Museen", ActaAArtHist VIII, 85-88.

Cameron, A.D.E. 1973: Porphyrius: the Charioteer, Oxford.

Carandini, A. et al. 2018: "Napoli. Lo spettacolo è underground', Archeologia Viva, Anno XXXVII, N. 189, May/June 2018, 18-29.

Clark, G. 2008: Women in Late Antiquity. Pagan and Christian Lifestyles (reprint from 1993 ed.), Oxford.

Deichmann, F.W. 1958: Ravenna, Hauptstadt des spätantiken Abenlandes, 1, Wiesbaden.
Del Bufalo, D. 2010: Marmorari magistri romani, Rome.

Del Bufalo, D. 2012: Porphyry. Red Imperial Porphyry. Power and Religion, Torino-LondonVenezia-New York.

Delbrück, R. 1913: "Porträts byzantinischer Kaiserinnen", $R M$ 28, 310-352.

Delbrück, R. 1914: “Carmagnola (Porträt eines byzatinischen Kaisers)", $R M$ 29, 71-89.

Delbrück 1933: Spätantike Kaiserporträts von Constantinus Magnus bis zum Ende des Westreiches, Berlin.

Dillon, S. 2010: The Female Portrait Statue in the Greek World, Cambridge.

Dunbabin, K.M. 1978: The Mosaics of Roman North Africa. Studies in Iconography and Patronage, Oxford.

Esoli, S., La Rocca, E. (eds.) 2000: Aurea Roma. Dalla città pagana alla città cristiana, Roma.

Fejfer, J. 2008: Roman Portraits in Context, Berlin.

Firatl1, N. 1990: La sculpture byzantine figurée au Musée Archéologique d'Istanbul, Paris.

Fittschen, K., Zanker, P. 1983: Katalog der römischen Porträts in den Capitolinischen Museen und anderen kommunalen Sammlungen der Stadt Rom III, Mainz.

Fradier, G. 1976: Mosaïques de Tunisie, Tunis.

Gehn, U. 2016: "Athens", in Smith, Ward-Perkins 2016, 190-199.

Gehn, U., Ward-Perkins, B. 2016: "Constanti-nople", in Smith, Ward-Perkins 2016, 136-144.

Grabar, A. 1967: Die Kunst im Zeitalter Justinians, München.

Harrison, M. 1989: A Temple for Byzantion. The Discovery and Excavation of Anicia Juliana's Palace Church in Istanbul, London.

Von Heintze, H. 1986: "Nordsyrische Elfenbeinstatuetten. Zu den Bildnissen des Kaisers Julians“, in O. Feld, U. Peschlow (eds.), Sudien zur Spätantiken und byzantinischen Kunst Friedrich Wilhelm Deichmann gewidmet, 3, Bonn, 31-41.

Holum, K.G. 1982: Theodosian Empresses, BerkeleyLos Angeles-London.

Inan, J., Rosenbaum, E. 1966: Roman and Early Byzantine Portrait Sculpture in Asia Minor, London.

Inan, J., Alföldi-Rosenbaum, E. 1979: Römische und frühbyzantinische Porträtskulptur aus der Türkei., neue Funde, Mainz. 
Karpp, H. 1966: Die frühchristlichen und mittelalterlichen Mosaiken in Santa Maria Maggiore zu Rom, Baden-Baden.

Kiilerich, B. 1993: Late Fourth Century Classicism in the Plastic Arts, Odense.

Kiilerich, B. 2001: "The Image of Anicia Juliana in the Vienna Dioscurides: Flattery or Appropriation of Imperial Imagery?", SymbOslo 76, 169-190.

Kiilerich, B. 2008: "Private portraits in late antiquity: observing the subject", in Roman Sculpture in Asia Minor. Proceedings of the International Conference to celebrate the $50^{\text {th }}$ anniversary of the Italian excavations at Hierapolis in Phrygia held on May 24-26, 2007, in Cavallino (Lecce), Portsmouth, Rhode Island, 359-370.

Kiilerich, B., Torp, H. 1989: "Hic est: hic Stilicho. The Date and Interpretation of a notable Diptych", JdI 104, 319-371.

Lenaghan, J. 2016: “Asia Minor", in Smith, WardPerkins 2016, 98-108.

L'Orange, H.P. 1961: "Der subtile Stil. Eine Kunstströmung aus der Zeit um 400 nach Christus", AntK 4, 68-74.

L'Orange, H.P. 1962: "Ein unbekanntes Porträt einer spätantiken Kaiserin“, ActaAArt Hist I, 49-52.

Meischner, J. 1997: "Der letzte Kaiser. Zum Porträt der nachtheodosianischen Epoche", in Bouzek, Ondrejová 1997, 45-47.

Meischner, J. 2001: Bildnisse der Spätantike 193-500: Problemfelder, die Privatporträts, Berlin.

Miltner, F. 1956: "XXI vorläufige Bericht über die Ausgrabungen in Ephesos", Öjh 43, 1-63.

Oberleitner, W. 1959: "Fragment eines spätantiken Porträtkopfes aus Ephesos”, ÖJh 44, 81-100.

Piccirillo, M. 1981: Chiese e mosaici della Giordania settentrionale, Jerusalem.

Piccirillo, M. 1993: The Mosaics of Jordan, Amman.

Prusac, M. 2016a: From Face to Face ( $2^{\text {nd }}$ revised ed.), Leiden-Boston.

Prusac, M. 2016b: "I ritratti del V e del VI secolo", in Andaloro, Bordi, Morganti 2016, 160-177.

Ravegnani, G. 2016: Teodora, Roma.

Sande, S. 1975: "Zur Porträtplastik des sechsten nachchristlichen Jahrhunderts”, ActaAArtHist VI, 65-106.
Schade, K. 2003: Frauen in der Spätantike - Status und Repräsentation. Eine Untersuchung zur römischen und frühbyzantinischen Bildniskunst, Mainz.

Schade, K. 2016: "Women", in Smith, Ward-Perkins 2016, 249-258.

Smith, R.R.R. 2016: "Statue Practice in the Late Roman Empire", in Smith, Ward-Perkins 2016, 1-27.

Smith, R.R.R., Ward-Perkins, B. (eds.) 2016: The Last Statues of Antiquity, Oxford.

Srejovic, D., Simovic, A. 1958-1959: "Portrait d'une impératrice byzantine de Balajnac", Starinar 7, 7786.

Stephens, J. "Ancient Roman Hairdressing: on (Hair)pins and Needles", JRA 21 (2008), 110-132.

Stichel, R.H.W. 1982: Die römische Kaiserstatue am Ausgang der Antike, Roma.

Stichel, R.H.W. 2005: "Review of J. Meischner, Bildnisse der Spätantike 193-500. Problemfelder, die Privatporträts", Gnomon 77, 66-70.

Strocka, V.M. 1985: "Zuviel Ehre für Scholastikia”, in M. Kandler, R. Pillinger, S. Karwiese (eds.), Lebendige Altertumswissenschaft. Festgabe zur Vollendung des 70. Lebensjahres von Herrmann Vetters, dargebracht von Freunden, Schülern und Kollegen, Wien.

Talgam, R. 2014: Mosaics of Faith. Floors of Pagans, Jews, Samaritans, Christians, and Muslims in the Holy Land, Jerusalem-University Park PA.

Trillmich, W. 1976: Das Torlonia-Mädchen: zu Herkunft und Entstehung des kaiserzeitlichen Frauenporträts, Göttingen.

Volbach, W.F. 1976: Elfenbeinarbeiten der Spätantike und des frühen Mittelalters, Mainz.

Volbach, W.F., Lafontaine Dosogne, J. 1968: Byzanz und der christliche Osten (Propyläen Kunstgeschichte 3), Berlin.

Wamser, L. (ed.) 2004: Die Welt von Byzanz - Europas östliches Erbe (exhibition catalogue), München.

Weitzmann, K. (ed.) 1979: Age of Spirituality. Late Antique and Early Christian Art, Third to Seventh Century. Catalogue of the Exhibition at the Metropolitan Museum of Art, November 19, 1977, through February 12, 1978, New York.

Wilpert, J., Schumacher, W.N. 1976: Die römischen Mosaiken der kirchlichen Bauten vom IV-XIII Jahrhundert, Freiburg-Basel-Wien. 

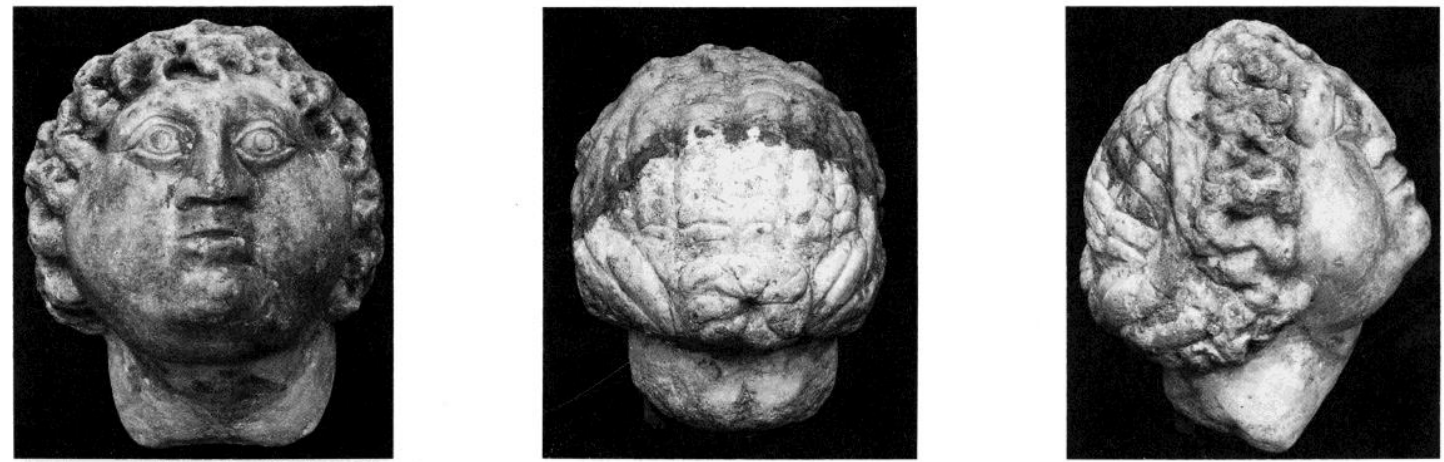

FIGS. 1-3 - Female portrait head in the Archaeological Museum of Istanbul. From Firatl1 1990, Pl. 12.
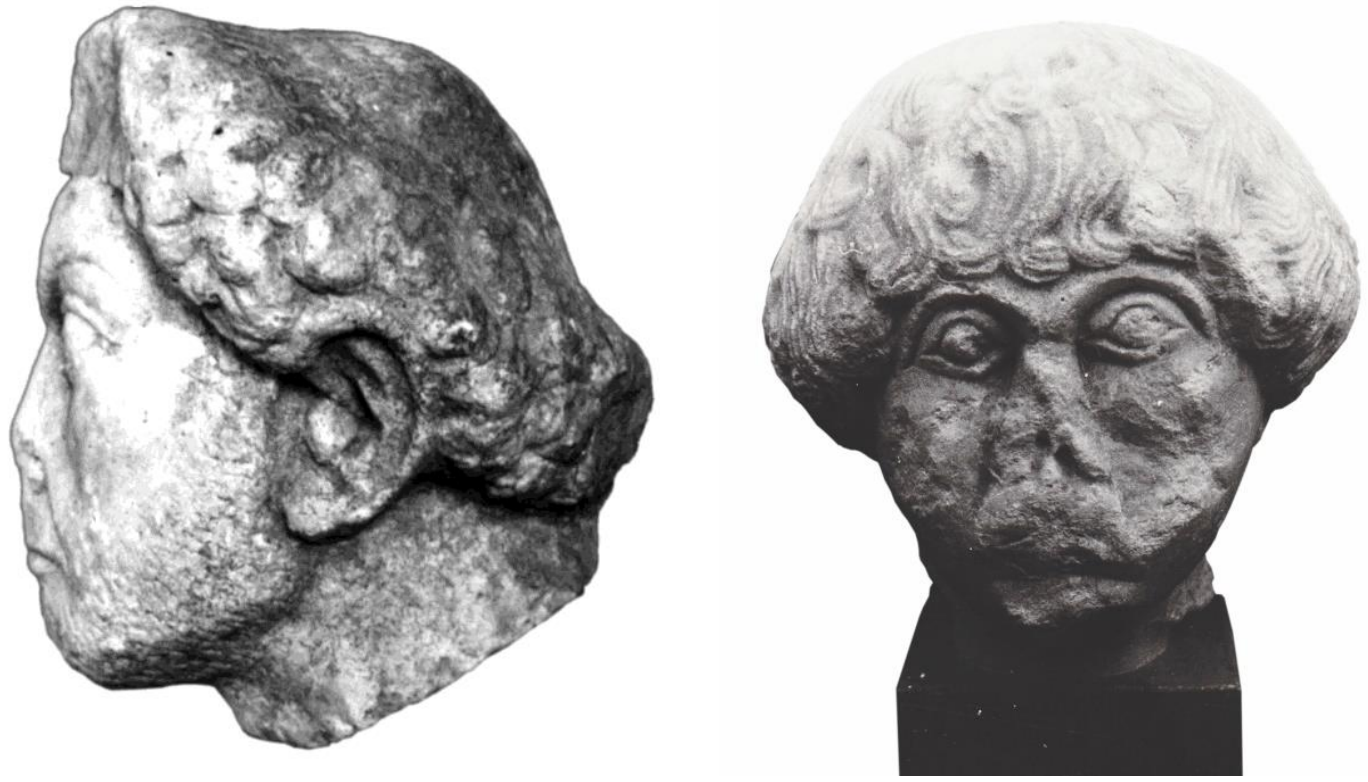

FIG. 4 - Male portrait head from Ephesus. Archaeological Museum, Selcuk. Photo Siri Sande.

FIG. 5 - Male portrait head from the environs of Balikesir, Turkey. Archaeological Museum of Istanbul. Photo Siri Sande. 


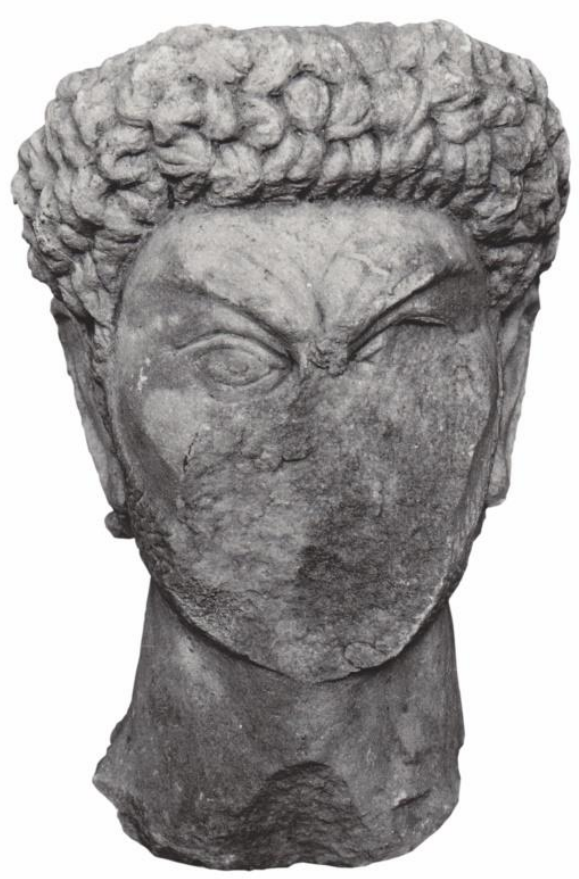

FIG. 6 - Male portrait head from Ephesus. Archaeological Museum, Selcuk. Photo Siri Sande.

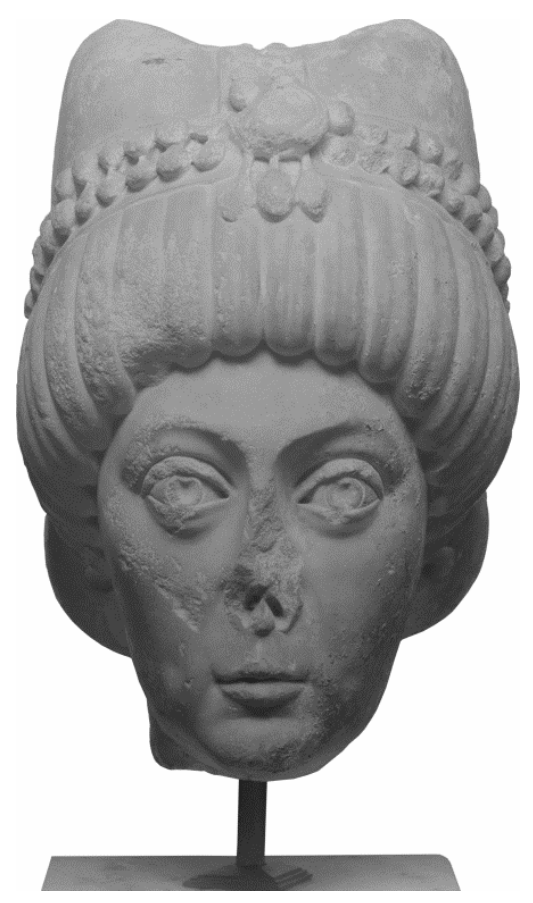

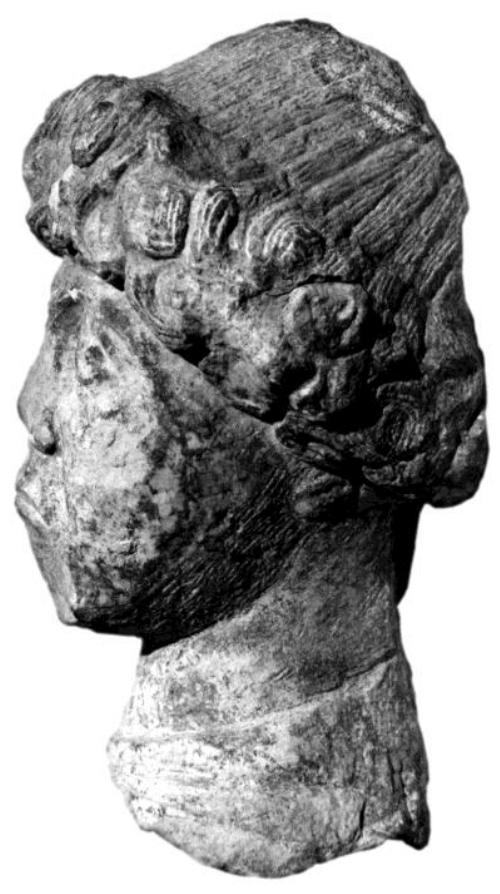

FIG. 7 - Male portrait head from Sardes. Sardes, Depot. Photo Siri Sande.

FIG. 8 - Portrait head of empress (Theodora?). Castello Sforzesco, Milan. Photo: D.A.I. Rome. 

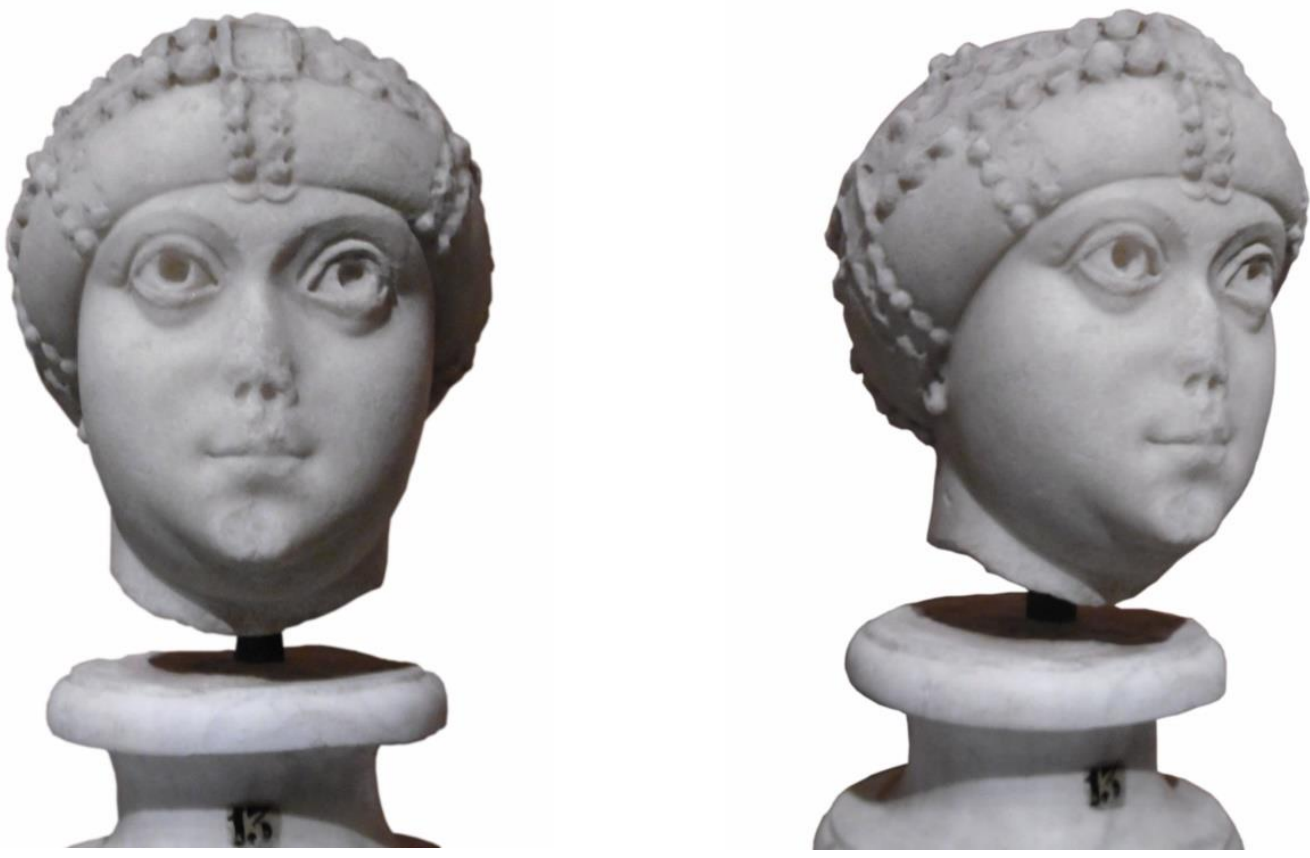

FIGS. 9-10 - Portrait had of empress or princess (so-called Ariadne). Musei Capitolini, Rome. Photo: Bente Kiilerich.

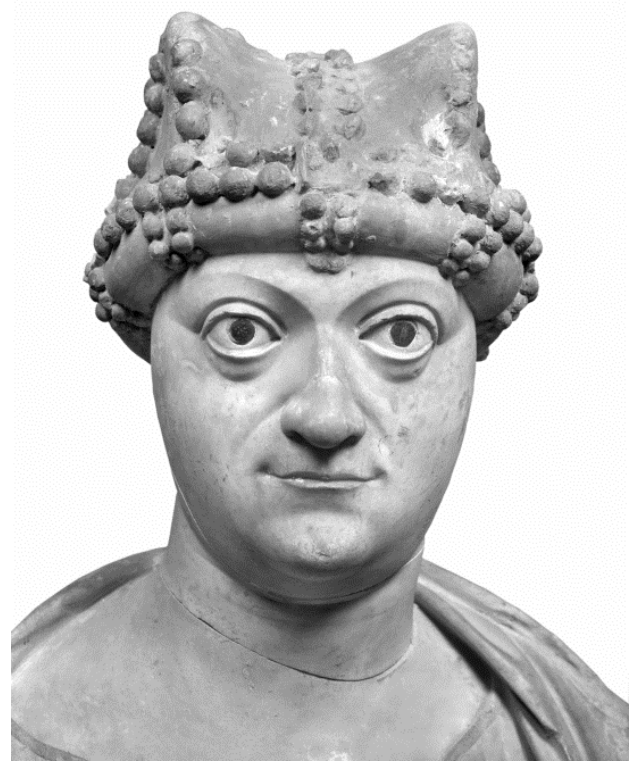

FIG. 11 - Portrait head of empress (so-called Ariadne). Lateran, Rome. Photo: D.A.I. Rome.

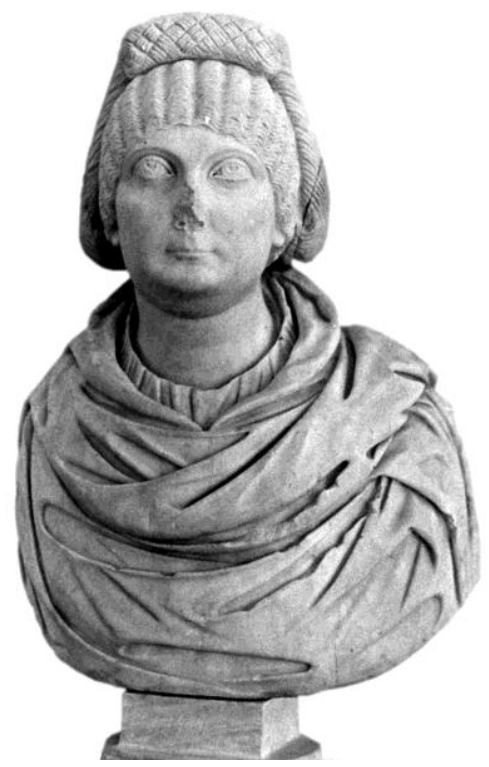

FIG. 12 - Female portrait bust from Thessaloniki. Archaeological Museum of Thessaloniki. Photo: Hjalmar Torp. 


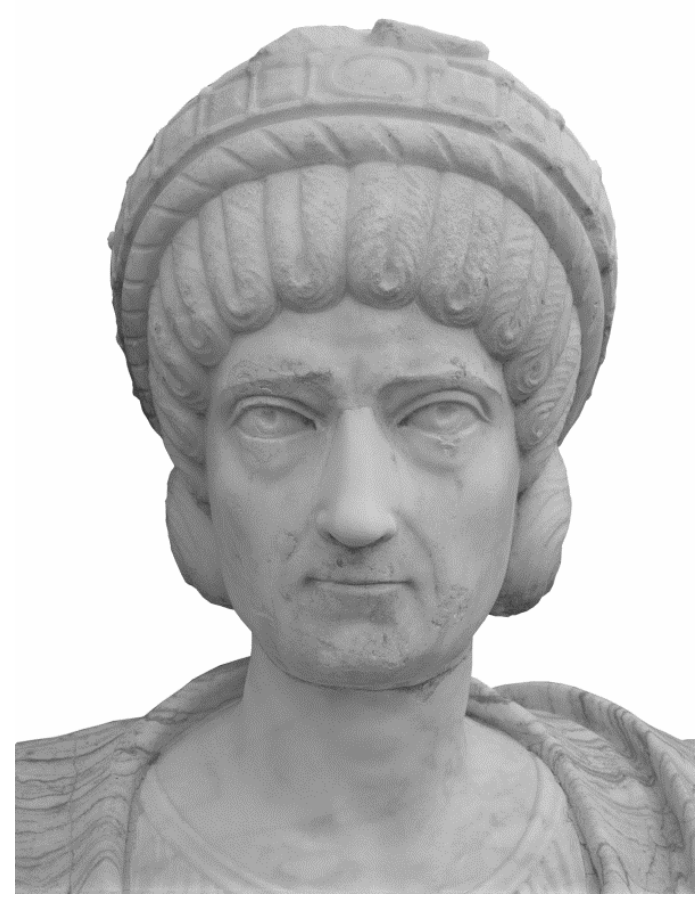

FIG. 13 - Portrait head of empress (Galla Placidia?). FIG. 14 - Portrait head of empress (Galla Placidia?).

Museo dell'Alto Medioevo, Rome. Photo: D.A.I. Museo dell'Alto Medioevo, Rome. Photo: D.A.I. Rome. Rome.

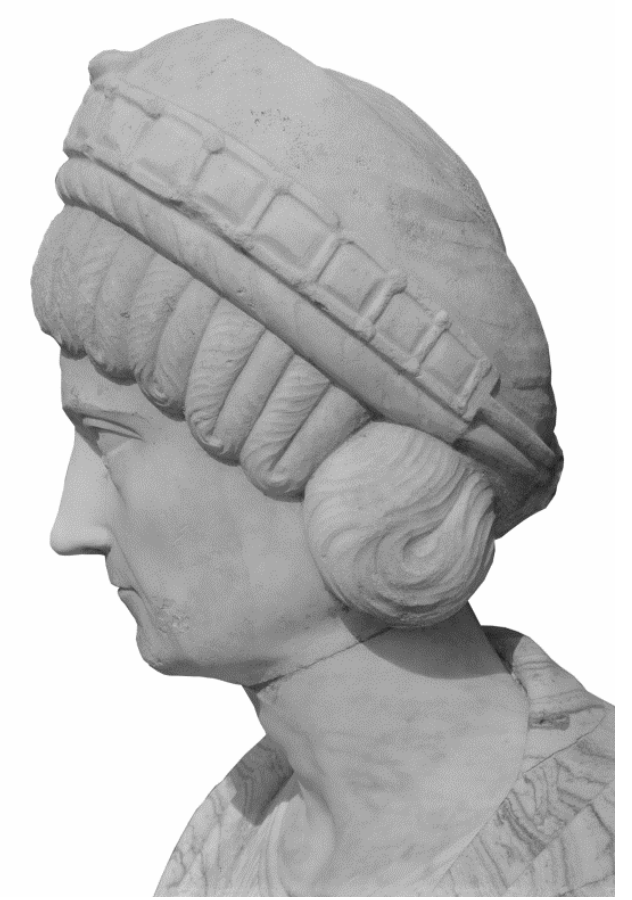


